$\$=1$

\title{
Prevalence and associated comorbidities of body mass index ranges
}

\author{
Jaspinder Kaur ${ }^{1}$, Sargun Singh ${ }^{2}$, Kawaljit Kaur ${ }^{3 *}$ \\ ${ }^{1}$ Medical Officers, Ex-servicemen Contributory Health Scheme (ECHS) Polyclinic, Sultanpur Lodhi, \\ District Kapurthala, Punjab (India)-144626. Current address: ECHS Polyclinic, Kapurthala, Punjab, India- 144601 \\ ${ }^{2}$ Medical Intern, Government Medical College, Amritsar, Punjab (India)-143001 \\ ${ }^{3}$ Associate Prof. \& HOD, Dept. of Biology, B.D. Arya Girls College, Jalandhar Cantt, Punjab (India)-144005 \\ *Corresponding author E-mail: virk.khokhar@yahoo.com
}

\begin{abstract}
Obesity is a global preventable epidemic inundating health care resources by increasing mortality and morbidity. The present study aimed to determine prevalence, risk factors, and co-morbidities associated with body mass index (BMI) ranges. A cross-sectional study was conducted to assess physical activity, dietary habits, alcohol, family history, sleep, stress, gender, age, education, employment and socioeconomic status as determinants of BMI. Total prevalence of overweight and obesity was reported among $33.34 \%$ and $18.24 \%$ of subjects, respectively; which increases with age $(76.55 \%)$ and declines thereafter $(21.87 \%)$. Female gender, primary and secondary education, middle social class, unemployment, positive family history, physical inactivity $(p<0.001)$, non-vegetarian diet $(p<0.05)$, adequate sleep, and significant stress was found associated with overweight and obesity. The prevalence of hypertension $(\mathrm{p}<0.05)$, hyperglycaemia $(\mathrm{p}<0.05)$, and hyperlipidemia was found directly proportional to increase in BMI. A rapidly rising obesity and its associated comorbidities show that almost all the factors were potentially modifiable and preventable through lifestyle modification, which includes Dietary Approach to Stop Hypertension, daily 30minutes moderate-intensity physical activity and stress management.
\end{abstract}

Keywords: Body Mass Index; Overweight; Obesity; Physical Activity; Preventable.

\section{Introduction}

Obesity is a global preventable epidemic inundating health care resources by increasing mortality and morbidity (WHO 2002). Around $35 \%$ of adults aged 20 years and over were overweight, and $11 \%$ were obese accounting nearly 2.0 billion people worldwide at a risk of overweight and obesity associated morbidities, including $44 \%$ of the diabetes burden, $23 \%$ of the ischemic heart disease burden, and between $7 \%$ and $41 \%$ of certain cancer burdens, and thus listing overweight and obesity as the fifth leading risk for global deaths. Furthermore, $65 \%$ of the world's population lives in countries where overweight and obesity kills more people than underweight (http://www.who.int/mediacentre/factsheets/fs311/en/). Nearly, 280,000 and 325,000 deaths could be attributed to obesity annually in the United States with more than $80 \%$ of these deaths among people with a body mass index (BMI) greater than $30 \mathrm{~kg} / \mathrm{m}^{2}$ (Allison et al. 1999). Moreover, the Centre for Disease Control and Prevention estimated an extra 400,000 lives may be lost per year when sedentary lifestyle is coupled with a poor diet; putting this lifestyle issues just behind smoking as a leading cause of death in the United States (Mokdad et al. 2004).

Obesity constitutes excess body fat which has accumulated to the extent that can cause adverse health effects leading to a reduced life expectancy and/or increased health problems (Haslam \& James 2005). BMI defined as the weight in kilograms divided by the height in meters squared $\left(\mathrm{kg} / \mathrm{m}^{2}\right)$, is the most widely used measure of obesity due to its low-cost and simplicity. The World Health Organization (WHO) and the National Institutes of health (NIH) have defined overweight as having a BMI between 25.00 and $29.99 \mathrm{~kg} / \mathrm{m}^{2}$; and obesity as a BMI greater than $30.00 \mathrm{~kg} / \mathrm{m}^{2}$ (WHO 2008). However, BMI does not discriminate between muscle and adipose tissue, and does not directly assess regional adiposity. Furthermore, waist circumference, hip circumference, and waist-to-hip ratios are the commonly used measures of abdominal obesity, rather than total body fat, which are found highly correlated with cardiovascular disease risk factors and diabetes than BMI (Stevens et al. 2008).

A complex interplay of individual genetic predisposition and environmental factors of surplus energy dense food availability and sedentary lifestyle contributes to obesity (Haslam \& James 2005). Genetic predisposition has shown a child of two obese parents has about $80 \%$ chance of becoming obese, whereas the risk is only $15 \%$ for the offspring of two normal-weight parents (O'Rahilly \& Farooqi 2006). However, few cases are caused primarily by endocrine disorders (e.g., hypothyroidism, Cushing's syndrome, growth hormone deficiency), medications (e.g., steroids, sulfonylureas, thiazolidinediones, atypical antipsychotics, antidepressants, phenytoin, valporate), or psychiatric illnesses (Haslam \& James 2005). The effects of an obesity result from two factors: an increased adipose tissue and increased secretion of pathogenetic products from enlarged fat cells. In the former, categories are the social disabilities resulting from the stigma associated with obesity (Fontaine et al. 1996); sleep apnoea from an increased parapharyngeal fat deposit (Strohl et al. 2004); and osteoarthritis resulting from 
the wear and tear on joints from carrying an increased fat mass (Felson et al.1988). The second category includes an insulinresistant state; development of diabetes mellitus from battling against insulin resistance; procoagulant state from an increased prothrombin activator inhibitor-1 secretion; endothelial dysfunction with an increased risk of atherothrombosis, cardiovascular disease and hypertension; cancers from an increased estrogen production; and thus constitutes metabolic syndrome (Kaur 2014).

Obesity should be approached as a chronic disease with genetic, environmental, and behavioral components. Although prospective studies of weight loss by obese persons have not demonstrated improvements in a long-term morbidity and mortality; reductions have been shown in the risk factors for several cardiovascular, pulmonary, and cancer conditions (WHO 2002). Thus, an orientation need for those tending towards being overweight and obesity on how to adopt healthier lifestyles is of paramount interest in public health. However, assessing the prevalence of overweight and obesity in the current study population is an initial process towards achieving this orientation. Hence, the present comparative study of socio-demographic variables and cardiovascular parameters of normal weight, overweight and obese subject was designed.

\section{Materials and methods}

2.1. Design overview: A multi cohort cross-sectional study was designed to observe the cardiovascular risk factors on the basis of BMI ranges. Patients who were registered with Ex-Servicemen Contributory Health Scheme (ECHS) Polyclinic located at Sultanpur Lodhi, Punjab (India) were recruited for the project. The selection for the present study was patients who had been retired from the defense services; their family members comprising spouse, parents and children; both genders aged above 20 years; and who attended the polyclinic from June, 2013 to Oct, 2013. The study was conducted in accordance with the Declaration of Helsinki, and the protocol was approved by the Institutional ethical committee. All subjects gave their written informed consent for inclusion before they participated in the study. The results were analyzed by Chi-Square test with $\mathrm{p}$ value $<0.05$ as statistically significant.

2.2. Information sources: We designed a multi-parameter, and pre-tested data collection forms on which the clinical history data, physical examination and biochemical tests were recorded. Questionnaire, Measuring Tape, Weighing Scale, BP Apparatus, Stethoscope, bacteriological incubator, Erba glucose kit (GOD-POD method, end point) and Erba cholesterol kits (CHOD-PAP method, end point) were used to collect the information. All instruments were checked for calibration before using them.

2.3.Body Mass Index (BMI): Weight measurements were taken with each subject standing at the centre of the weighing scale in light clothing, without shoes and socks. Height was determined using a wall mounted, non-extendable measuring tape with subjects standing in an erect barefoot position, arms by side, and feet together. The WHO (2008) has divided the weight into three categories: Normal weight $\left(18.50-24.99 \mathrm{~kg} / \mathrm{m}^{2}\right)$, Overweight $(\geq 25.00$ $\left.29.99 \mathrm{~kg} / \mathrm{m}^{2}\right)$ and Obesity $\left(\geq 30.00 \mathrm{~kg} / \mathrm{m}^{2}\right)$.

2.4. Clinical variables: Socio-demographic variables, lifestyle and cardiovascular risk factors were elaborated. Education level was classified into four categories: no/little formal, primary, secondary and graduation. Income adequacy was defined into lower, middle and upper on the basis of retired ranks of ex-servicemen, including their household income and assets. The regular aerobic physical activity (e.g., brisk walking) of at least 30 minutes per day for most days of the week was considered adequate (Chobanian et al. 2003). The family history was defined as positive if a first-degree male relative (e.g. father, brother) and female relative have the cardiovascular disease before the age of 55 or 65 years respectively (Chobanian et al. 2003). Job strain, social con- straints, financial un-stability, and emotional distress in the form of anxiety and/or depression were included under "stress." Men alcohol intake is limited to <2 drinks per day; and for women and lighter-weight persons, it is limited to $<1$ drink per day ( 1 drink $=$ $1 / 2 \mathrm{oz}$ or $15 \mathrm{ml}$ ethanol (e.g., $12 \mathrm{oz}$ beer, $5 \mathrm{oz}$ wine, $1.5 \mathrm{oz} 80$-proof whiskey)) (Chobanian et al. 2003). Subjects who presently use alcoholic beverages and/or exceed their limits were categorized under "Current" group; and those who had never or left their habit of heavy alcohol consumption were counted under "Ex/Never" group. Sleep adequacy evaluated on the basis of sleep duration (7 to $8 \mathrm{hrs}$ ), difficulty in initiating, multiple arousals and early awakenings. Blood pressure (BP) was measured in the right arm of the subject seated and rested for 5 minutes using a standard mercury sphygmomanometer and a suitable calibrated cuff. Hypertension was defined as a $B P \geq 140 / \geq 90 \mathrm{mmHg}$ or a previous diagnosis with being on anti-hypertensive therapy (Chobanian et al. 2003).

2.5. Biochemical analysis: A blood sample was obtained from all the pre-informed individuals after 8-10hours of fasting. Hyperglycaemia was diagnosed on the basis of fasting blood-glucose levels $>100 \mathrm{mg} / \mathrm{dl}(>5.6 \mathrm{mmol} / \mathrm{l})$ and $/$ or 2 hour postprandial blood-glucose levels $>140 \mathrm{mg} / \mathrm{dl}$ (>7.8mmol/l) (American Diabetes Association 2005). Hyperlipidemia was defined by a total cholesterol level $>200 \mathrm{mg} / \mathrm{dl}$ (>5.2mmol/l) (National Cholesterol Education Program 2002). It further includes those previously diagnosed with high cholesterol, impaired fasting glucose (IFG), impaired glucose tolerance (IGT) or diabetes mellitus and being on treatment for these disorders.

\section{Results}

All patients $(\mathrm{N}=351)$ were divided into three groups on the basis of the BMI ranges: normal weight $(\mathrm{N}=170 ; 48.44 \%)$; overweight $(\mathrm{N}=117 ; 33.34 \%)$ and obesity $(\mathrm{N}=64 ; 18.24 \%)$. Table 1 displays $04.11 \%, 18.23 \%, 39.42 \%$ and $38.26 \%$ of subjects with normal BMI were in 20-35years, 36-50years, 51-65years and $>65$ years of age group, while, overweight was seen among 03.41\%, 27.35\%, $34.18 \%$ and $35.04 \%$; and obesity in $01.56 \%, 28.12 \%, 48.43 \%$ and $21.87 \%$ for the same age groups, respectively. It shows an increase in obesity as age advances and decline by 65years of age (Figure 1).

Table 1: Comparisons of the Socio-Demographic Variables in All the Study Subjects*.

\begin{tabular}{|c|c|c|c|c|}
\hline Category & $\begin{array}{l}\text { Normal Weight } \\
(170)\end{array}$ & $\begin{array}{l}\text { Over Weight } \\
\text { (117) }\end{array}$ & $\begin{array}{l}\text { Obesity } \\
(64)\end{array}$ & $\begin{array}{l}\mathrm{p} \\
\text { value }\end{array}$ \\
\hline \multicolumn{5}{|c|}{ AGE (years) } \\
\hline $20-35$ & $04.11(07)$ & $03.41(04)$ & $01.56(01)$ & \multirow{4}{*}{10.12} \\
\hline $36-50$ & $18.23(31)$ & $27.35(32)$ & $28.12(18)$ & \\
\hline $51-65$ & $39.42(67)$ & $34.18(40)$ & $48.43(31)$ & \\
\hline$>65$ & $38.26(65)$ & $35.04(41)$ & $21.87(14)$ & \\
\hline \multicolumn{5}{|c|}{ GENDER } \\
\hline Male & $51.77(88)$ & $48.71(57)$ & $43.75(28)$ & \multirow{3}{*}{1.23} \\
\hline Female & $48.26(82)$ & $51.28(60)$ & $56.25(36)$ & \\
\hline \multicolumn{4}{|c|}{ EDUCATION } & \\
\hline No/Little & $32.95(56)$ & 31.63 (37) & $21.87(14)$ & \multirow{4}{*}{8.97} \\
\hline Primary & $30.59(52)$ & $23.07(27)$ & $40.62(26)$ & \\
\hline Secondary & $30.59(52)$ & 40.17 (47) & $37.50(24)$ & \\
\hline Graduation & $05.89(10)$ & $05.12(06)$ & $00(00)$ & \\
\hline \multicolumn{5}{|c|}{ SOCIO ECONOMIC STATUS } \\
\hline Middle & $64.71(110)$ & $59.82(70)$ & $62.50(40)$ & \multirow{3}{*}{0.75} \\
\hline Upper & $35.30(60)$ & 40.17 (47) & $37.50(24)$ & \\
\hline \multicolumn{4}{|c|}{ OCCUPATION } & \\
\hline $\begin{array}{l}\text { Stays at } \\
\text { home }\end{array}$ & $70.00(119)$ & $72.64(85)$ & $67.18(43)$ & \multirow{2}{*}{0.62} \\
\hline Employed & $30.00(51)$ & $27.35(32)$ & $32.81(21)$ & \\
\hline
\end{tabular}

*parentheses represent absolute number of the subjects in a sample. 


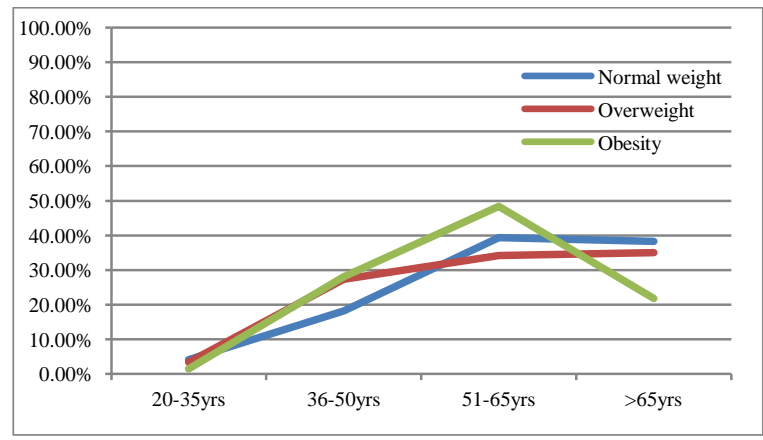

Fig. 1: Age Specific Prevalence of Body Mass Index Ranges

Among both genders, females were reported with a higher prevalence of obesity $(56.25 \%)$ and over-weight $(51.28 \%)$ than males (overweight: 48.71\%; and obesity: 43.75\%). Individuals with no/little, primary, secondary and graduation level education had $32.95 \%, 30.59 \%, 30.59 \%$ and $05.89 \%$ of normal weight respectively, while, $31.63 \%, 23.07 \%, 40.17 \%$ and $05.12 \%$ of them had been overweight; and $21.87 \%, 40.62 \%, 37.50 \%$ and $00.00 \%$ had obesity for the same education categories. This shows normal BMI range among individuals with little/no education $(32.95 \%)$ and graduation $(05.89 \%)$; and obesity $(40.62 \%)$ and overweight $(40.17 \%)$ in subjects with primary and secondary education, respectively. Taking socioeconomic status into consideration, obesity $(62.50 \%)$ and overweight $(59.82 \%)$ was more prevalent among middle than upper social class subjects (overweight: $40.17 \%$; and obesity: $37.50 \%$ ). Similarly, a higher prevalence of overweigh $(72.64 \%)$ and obesity $(67.18 \%)$ was observed in subject who stays at home than employed individuals (over-weight: $27.35 \%$; and obesity: $32.81 \%$ ).

Table 2 reflects a higher prevalence of obesity (37.50\%) and overweight $(33.33 \%)$ among subjects with positive cardiovascular family history than normal weight $(30.00 \%)$. An inverse association of alcohol and BMI was found, where subjects under no effects of alcoholic beverages had a higher prevalence of overweight $(76.92 \%)$ and obesity $(73.43 \%)$ than with a history of heavy alcohol consumption (overweight: $23.07 \%$; and obesity: $26.56 \%$ ). A statistically significant sedentary lifestyle had shown a predisposition to obesity $(71.87 \% ; \mathrm{p}<0.001)$ and overweight $(65.81 \%$; $\mathrm{p}<0.001)$; and active lifestyle to normal weight $(55.30 \%$; $\mathrm{p}<0.001)$. Furthermore, a statistically significant relation of nonvegetarian diet with obesity $(53.12 \% ; \mathrm{p}<0.05)$, and vegetarianism with normal weight $(65.30 \%$; $\mathrm{p}<0.05)$ was found. A positive relation between sleep and BMI was reported, where adequate sleep promotes obesity $(73.43 \%)$ and overweight $(70.94 \%)$ than inadequate sleep (overweight: $29.05 \%$; and obesity: $26.56 \%$ )., Moreover, stress had shown a relation with overweight $(21.36 \%)$ and obesity $(20.31 \%)$ than normal weight $(18.24 \%)$.

Table 2: Comparison of Risk Factors in All the Study Subjects*

\begin{tabular}{|c|c|c|c|c|}
\hline Category & $\begin{array}{l}\text { Normal Weight } \\
(170)\end{array}$ & $\begin{array}{l}\text { Over Weight } \\
\text { (117) }\end{array}$ & $\begin{array}{l}\text { Obesity } \\
(64)\end{array}$ & $\begin{array}{l}\mathrm{p} \\
\text { value }\end{array}$ \\
\hline \multicolumn{5}{|c|}{ FAMILY HISTORY } \\
\hline Positive & $30.00(51)$ & $33.33(39)$ & $37.50(24)$ & \multirow{2}{*}{1.28} \\
\hline Negative & $70.00(119)$ & $66.66(78)$ & $62.50(40)$ & \\
\hline \multicolumn{5}{|c|}{ ALCOHOL CONSUMPTION } \\
\hline Yes & $24.71(42)$ & $23.07(27)$ & $26.56(17)$ & \multirow[b]{2}{*}{0.31} \\
\hline No & $75.30(128)$ & $76.92(90)$ & $73.43(47)$ & \\
\hline \multicolumn{5}{|c|}{ PHYSICAL ACTIVITY } \\
\hline Adequate & $55.30(94)$ & $34.18(40)$ & $28.12(18)$ & \multirow{2}{*}{$<0.001$} \\
\hline In adequate & $44.71(76)$ & $65.81(77)$ & $71.87(46)$ & \\
\hline \multicolumn{5}{|c|}{ DIETARY HABITS } \\
\hline Vegetarian & $65.30(111)$ & $59.82(70)$ & $46.87(30)$ & \multirow[b]{2}{*}{$<0.05$} \\
\hline Non- & $34.71(59)$ & $40.17(47)$ & $53.12(34)$ & \\
\hline \multicolumn{5}{|c|}{ SLEEP } \\
\hline Adequate & $71.77(122)$ & $70.94(83)$ & $73.43(47)$ & \multirow{3}{*}{0.15} \\
\hline In adequate & $28.24(48)$ & $29.05(34)$ & $26.56(17)$ & \\
\hline & & TRESS & & \\
\hline Yes & $18.24(31)$ & $21.36(25)$ & $20.31(13)$ & \multirow{2}{*}{0.49} \\
\hline No & $81.77(139)$ & $78.63(92)$ & $79.68(51)$ & \\
\hline
\end{tabular}

Table 3 reveals a statistically significant higher prevalence of hypertension, hyperglycemia and hyperlipidemia in overweight (hypertension: $51.29 \% \quad(\mathrm{p}<0.05)$; hyperglycemia: $27.36 \%$ $(\mathrm{p}<0.05)$; and hyperlipidemia: $32.48 \%)$ and obese (hypertension: $64.07 \%(\mathrm{p}<0.05)$; hyperglycemia: $35.94 \%(\mathrm{p}<0.05)$; and hyperlipidemia: $32.82 \%$ ) than normal weight subjects (hypertension: $42.36 \%(\mathrm{p}<0.05)$; hyperglycemia: $18.83 \%(\mathrm{p}<0.05)$; and hyperlipidemia: $24.71 \%$ ). Figure 2 further reveals an increase in prevalence of hypertension, hyperglycemia and hyperlipidemia with BMI

Table 3: Comparisons of the Comorbidities in Body Mass Index Ranges Among All the Study Subjects*

\begin{tabular}{lllll}
\hline Category & $\begin{array}{l}\text { Normal } \\
\text { Weight }(170)\end{array}$ & $\begin{array}{l}\text { Over Weight } \\
(117)\end{array}$ & $\begin{array}{l}\text { Obesity } \\
(64)\end{array}$ & $\begin{array}{l}\mathrm{p} \\
\text { value }\end{array}$ \\
Hypertension & $42.36(72)$ & $51.29(60)$ & $\begin{array}{l}64.07 \\
(41)\end{array}$ & $<0.05$ \\
Normotension & $57.65(98)$ & $48.72(57)$ & $\begin{array}{l}35.94 \\
(23)\end{array}$ & \\
Hyperglycaemic & $18.83(32)$ & $27.36(32)$ & $\begin{array}{l}35.94 \\
(23)\end{array}$ & $<0.05$ \\
Euglycemic & $81.18(138)$ & $72.65(85)$ & $\begin{array}{l}64.07 \\
(41)\end{array}$ & \\
Hyperlipidemic & $24.71(42)$ & $32.48(38)$ & $\begin{array}{l}32.82 \\
(21)\end{array}$ & 2.67 \\
Normolipidemic & $75.30(128)$ & $67.53(79)$ & $\begin{array}{l}67.19 \\
(43)\end{array}$ & \\
\hline
\end{tabular}

*parentheses represent absolute number of the subjects in a sample.

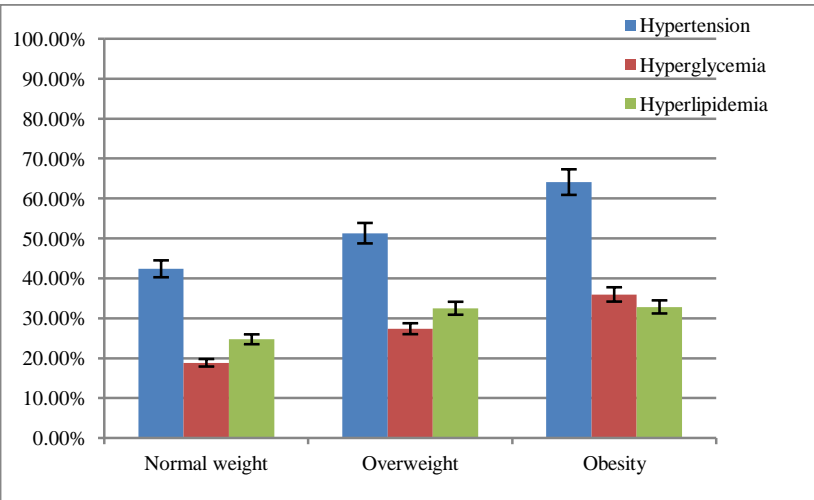

Fig. 2: Graphical Presentation of Comorbidities of Body Mass Index Ranges

\section{Discussion}

WHO has described obesity as a first defined cluster of noncommunicable diseases called "New World Syndrome," creating an enormous socioeconomic burden by affecting every global region (Pednekar 2008). The current study was designed to elaborate the determinants and effects of body mass index ranges on the cardiovascular health of the study subjects.

The current study observed overweight and obesity among $33.34 \%$ and $18.24 \%$ of subjects, respectively. Similarly, Chukwuonye et al. (2013) has found the prevalence of overweight and obese individuals ranged from $20.3 \%-35.1 \%$ and $8.1 \%$ $22.2 \%$ in Nigeria, respectively. However, Adienbo et al. (2012) has a contrary finding of higher prevalence of obesity $(49.34 \%)$ than overweight $(22.04 \%)$. Transport facilities, medical care, food resources, educational status, and family income had been dramatically improved in the rural areas and/or small towns/cities which along with an easy access to established cities, television watching and internet access resulted in changed lifestyle, and subsequently contributed to obesity and its associated metabolic co-morbidities (Ramachandran \& Snehalatha 2010). Furthermore, the number of drugs, including antidepressants (e.g. serotonin re-uptake inhibitors), oral hypoglycemic agents (e.g. insulin, sulphonylureas and thiazolidinediones) and antihypertensive (e.g. beta adrenergic receptor antagonists) taken by the study population might have led to an increased weight and BMI (Haslam \& James 2005). 
The current study (Table 1) reported a higher prevalence of obesity among subjects belonging to be 35-65years of age group $(76.55 \%)$ and found a decline in weight $(21.87 \%)$ thereafter. Data from both National Health and Nutrition Examination Survey III (NHANES) and Behavioral Risk Factor Surveillance System shows an increase in obesity until age of 60 years, with a steady and subsequent decrease in the older age groups (Mokdad et al .2001). The prevalence of obesity has been shown to be agedependent, with a characterizing " $U$ " or " $J$ " shaped distribution pattern. Further, Tiwari et al. (2009) has depicted an increase in BMI with age advancement with maximum prevalence among age groups 50-60years in males and more than 70years in females. An increase in obesity with age probably results from a reduced physical activity (Amira et al .2012), decrease in height (Lim et al .2000 ), drop in energy expenditure due to a decline in resting metabolic rate (Luhrmann et al .2010), and further, an age-related reduction in fat-free mass with proportionate loss of the more metabolically active and energy-burning muscle tissue with age (St-Onge \& Gallagher 2010).

A higher prevalence of overweight (51.28\%) and obesity (56.25\%) in females than males in the present study was found supported by al-Nuaim et al. (1996). Alterations in ovarian hormones and a shift to an abdominal fat distribution from gynaeoid obesity due to a relative increase in the androgen-estrogen ratio in postmenopausal women might contribute to a higher BMI among women than men, especially after 50years of age (Björntorp 1993). Conversely, Tiwari et al. (2009) has observed an increased BMI among taller and heavier males than females.

The current study noticed normal weight among subjects with little/no education (32.95\%) and graduated subjects (05.89\%); and overweight and obesity in subjects with primary $(63.69 \%)$ and secondary education $(77.67 \%)$, respectively. However, studies in Europe and USA have noticed that educational inequalities are related with increased BMI, which shows overweight or obesity among individuals with lower educational attainment (Roskam et al .2010; Yu 2012). A higher education provides lifestyle and nutritional awareness with active lifestyle preventing the obesity (Yusuf et al .2012). Conversely, a national survey in South Africa demonstrated that women with greater than 12 years of education had higher BMIs than women with 1-12years of education, which might be contributed to a higher levels of manual labour in the latter group than the more educated women being employed in a corporate sector (Puoane et al .2002). The present study found a higher prevalence of overweight and obesity among middle than upper social class subjects, which might be attributed to limited opportunity to have a healthy eating choices and physical leisuretime activity for being involvement of the former groups in low activity jobs with prolonged working hours. However, McLaren (2007) stated that women, men, and children from high social classes in the developing world are seen to have greater rates of obesity due to the globalization effects.

The current study observed being at home, either as a homemaker, retiree or unemployed person has shown a predisposition to obesity than being employed. Similarly, Kang et al. (2013) has reported unemployment to be significantly related to a higher obesity risk regardless of age, lifestyle, socioeconomic factors, and inflammatory factor. Contrarily, Ko et al. (2007) found subjects employed with long working hours (>9hours) and short sleeping hour (6hours or less) had the highest BMI and waist circumference in both sexes.

A higher prevalence (Table 2) of overweight $(33.33 \%)$ and obesity (37.50\%) than normal weight $(30.00 \%)$ among the present study subjects with positive cardiovascular family history has been found consistent to Hajian-Tilaki and Heidari (2007). Similarly, Van der Sande et al. (2001) found family history of hypertension, obesity, diabetes, or stroke was a significant risk factor for obesity and hyperlipidemia. The current study found a negative association between obesity and alcohol consumption, where various epidemiologic data showed that a positive, negative, or no relationship between alcohol intake and body weight was influenced by body weight, diet, genetic factors, gender and physical activity levels as well as frequency, pattern, amount of consumption and types of drinks consumed (Suter 2005). Furthermore, French et al. (2010) noticed alcohol as a complement to sedentary activities of watching television and attending sporting events which subsequently promotes weight gain.

A statistically significant association of sedentary behavior with overweight $(65.81 \%$; $\mathrm{p}<0.001)$ and obesity $(71.87 \%$; $<<0.001)$ has shown persistence to Davis et al (2006) in the present study. Similarly, Yancey et al. (2004) studied an association between sedentary behavior and overweight; and found lower educational attainment, female gender, advancing age, poorer self-perceived health status, self-perceived depression, smoking, leisure-time television watching/computer use, and receiving a diabetes diagnosis to be significantly related to sedentariness.

A statistically significant association of non-vegetarian and vegetarian diet with obesity $(53.12 \%$; $\mathrm{p}<0.05)$, and normal weight $(65.30 \% ; \mathrm{p}<0.05)$ was found in the present study, respectively. Similarly, Serena et al. (2009) reported mean BMI was lowest in vegans $\left(23.6 \mathrm{~kg} / \mathrm{m}^{2}\right)$ and incrementally higher in lacto-ovovegetarians $\left(25.7 \mathrm{~kg} / \mathrm{m}^{2}\right)$, pesco-vegetarians $\left(26.3 \mathrm{~kg} / \mathrm{m}^{2}\right)$, semivegetarians $\left(27.3 \mathrm{~kg} / \mathrm{m}^{2}\right)$, and non-vegetarians $\left(28.8 \mathrm{~kg} / \mathrm{m}^{2}\right)$. Conversely, Brathwaite et al. (2003) observed a significant association between vegetarian diet and obesity. However, Tiwari et al. (2009) has noted no significant difference in the BMI ranges and dietary profile of the participant. Vegetarian diet is rich in vegetables and fruits, and typically includes foods with low glycemic index such as beans, legumes, and nuts, which reduces oxidative stress and chronic inflammation and thus favor low BMI (Serena et al. 2009).

The present study observed a higher BMI in subjects who take adequate sleep. Garcia et al. (2008) noticed sleeping $<5$ hours or $>8$-9hours was associated with obesity among older adults. However, Vioque et al. (2000) reported sleep $\geq 9 \mathrm{~h} /$ day presented a lower prevalence of obesity than those sleeping $\leq 6 \mathrm{~h} / \mathrm{day}$. The present study found a predisposition of stress to be overweight $(21.36 \%)$ and obesity (20.31\%) than normal weight (18.24\%). Furthermore, Barrington et al. (2012) found association of perceived stress with several obesogenic behaviors of lower eating awareness levels with fewer fruit and vegetables servings, greater fast food consumption, and being sedentary.

The current study recorded a statistically significant higher prevalence of hypertension $(p<0.05)$, hyperglycemia $(p<0.05)$, and hyperlipidemia in overweight and obese than normal-weight subjects (Table 3). Similarly, NHANES (1998) has shown a remarkable and linear relationship between a rise in BMI and systolic, diastolic, and pulse pressures in the American population. Furthermore, Gothankar (2011) and Veghari et al. (2013) found a similar positive association of BMI with diabetes and serum cholesterol levels, respectively.

A lifestyle modification should be encouraged for weight loss and maintenance, which includes dietary approach to stop hypertension (DASH), daily minimum 30minutes of moderate-intensity physical activity for the most days of the week and stress management. Persons who combine calorie restriction and exercise with behavioral modifications should expect to lose 5-10\% of preintervention weight over a period of four to six months, which helps to improve various obesity-related co-morbidities.

\section{Conclusion}

A rapidly rising obesity and its associated co-morbidities cost an enormous burden on the health care system due to its long-term health consequences affecting individual, family and nation. However, almost all the factors were potentially modifiable and preventable, which requires better understanding of the causes to overcome the barriers for the primary prevention of obesity among youth and adults to achieve a healthy weight, and to ensure the country's health. 


\section{Acknowledgement}

We acknowledge all the patients who gave their permission to be a part of this study and the entire staff of the polyclinic for their consistent support and Ms Manjit Kaur for her assistance in the statistical analysis.

\section{Financial Support}

None.

\section{Conflict of Interest}

None.

\section{References}

[1] Adienbo OM, Hart VO \& Oyeyemi WA (2012), High Prevalence of Obesity among Indigenous Residents of a Nigerian Ethnic Group: The Kalabaris in the Niger Delta Region of South-South Nigeria. Greener Journal of Medical Sciences, 2, 152-156.

[2] Allison DB, Fontaine KR, Manson JE, Stevens J \& VanItallie TB (1999), Annual deaths attributable to obesity in the United States. The Journal of the American Medical Association, 282, 1530-1538. http://dx.doi.org/10.1001/jama.282.16.1530.

[3] al-Nuaim AR, al-Rubeaan K, al-Mazrou Y, al-Attas O, al-Daghari N \& Khoja T (1996), High prevalence of overweight and obesity in Saudi Arabia. International Journal of Obesity and Related Metabolic Disorders. 20, 547-552.

[4] American Diabetes Association (2005), Clinical practice recommen dations. Diabetes Care, 28, S1-79.

[5] Amira CO, Sokunbi DOB \& Sokunbi A (2012), the prevalence of obesity and its relationship with hypertension in an urban community: Data from world kidney day screening programme. International Journal of Medicine \& Biomedical Research, 1, 104-110. http://dx.doi.org/10.14194/ijmbr.124.

[6] Available at http://www.who.int/mediacentre/factsheets/fs311/en/. Accessed January 2, 2015.

[7] Barrington WE, Ceballos RM, Bishop SK, McGregor BA \& Beresford SAA (2012), Perceived Stress, Behavior, and Body Mass Index among Adults Participating in a Worksite Obesity Prevention Program, Seattle, 2005-2007. Prev Chronic Dis, 9, 120001. http://dx.doi.org/10.5888/pcd9.120001.

[8] Björntorp P (1993), Endocrine insufficiency and nutrition in aging. Aging, 5, 45-49.

[9] Brathwaite N, Fraser HS, Modeste N, Broome H \& King R (2003), Obesity, diabetes, hypertension, and vegetarian status among SeventhDay Adventists in Barbados: preliminary results. Ethnicity \& Disease, 13, 34-39.

[10]Chobanian AV, Bakris GL, Black HR, Cushman WC, Green LA \& Izzo JL Jr. et al. (2003), Joint National Committee on Prevention, Detection, Evaluation, and Treatment of High Blood Pressure; Nationa Heart, Lung, and Blood Institute; National High Blood Pressure Education Program Coordinating Committee: Seventh report of the Joint National Committee on Prevention, Detection, Evaluation, and Treatment of High Blood Pressure. Hypertension, 42, 1206-1252. http://dx.doi.org/10.1161/01.HYP.0000107251.49515.c2.

[11] Chukwuonye IJ, Chuku A, John C, Ohagwu KA, Imoh ME, Isa SE, Ogah OS \& Oviasu E (2013), Prevalence of overweight and obesity in adult Nigerians - a systematic review. Diabetes, Metabolic Syndrome and Obesity: Targets and Therapy, 6, 43-47. http://dx.doi.org/10.2147/DMSO.S38626

[12] Davis JN, Valerie AH \& Beth G (2006), Physical activity compliance: differences between overweight/obese and normal-weight adults Obesity, 14, 2259 -2265. http://dx.doi.org/10.1038/oby.2006.265.

[13]Felson DT, Anderson JJ, Naimark A, Walker AM \& Meenan RF (1988), Obesity and knee osteoarthritis. The Framingham Study. Annals of Internal Medicine, 109, 18-24. http://dx.doi.org/10.7326/00034819-109-1-18.

[14]Fontaine KR, Cheskin LJ \& Barofsky I (1996), Health-related quality of life in obese persons seeking treatment. Journal of Family Practice, 43, 265-270

[15]French MT, Norton EC, Fang H \& Maclean JC (2010), Alcohol consumption and body weight. Health Economics, 19, 814-832. http://dx.doi.org/10.1002/hec.1521.
[16]Gothankar JS (2011), Prevalence of obesity and its associated comorbidities amongst adults. National Journal of Community Medicine, 2, 221-224.

[17]Hajian-Tilaki KO \& Heidari B (2007), Prevalence of obesity, central obesity and the associated factors in urban population aged 20-70 years, in the north of Iran: a population-based study and regression approach. Obesity Reviews, 8, 3-10. http://dx.doi.org/10.1111/j.1467789X.2006.00235.x.

[18] Haslam DW \& James WP (2005), Obesity. Lancet, 366, 1197-1209. http://dx.doi.org/10.1016/S0140-6736(05)67483-1.

[19] Kang HT, Lee HR, Lee YJ, Linton JA \& Shim JY (2013), Relationship between employment status and obesity in a Korean elderly population, based on the 2007-2009 Korean National Health and Nutrition Examination Survey (KNHANES). Archives of Gerontology and Geriatrics, 57, 54-59. http://dx.doi.org/10.1016/j.archger.2013.02.004.

[20] Kaur J (2014), a comprehensive review of metabolic syndrome. Cardiology Research and Practice, article ID 943162, 21 pages.

[21]Ko GTC, Chan JCN, Chan AWY, Wong PTS, Hui SSC, Tong SDY, Ng SM, Chow F \& Chan CLW on behalf of the BHBHK Research Committee, the Health InfoWorld of Hong Kong Hospital Authority, Hong Kong SAR, China (2007), Association between sleeping hours, working hours and obesity in Hong Kong Chinese: the 'better health for better Hong Kong' health promotion campaign. International Journal of Obesity, 31, 254-260. http://dx.doi.org/10.1038/sj.ijo.0803389.

[22] Lim TO, Ding LM, Zaki M, Suleiman AB, Fatimah S, Siti S, Tahir A \& Maimunah AH (2000), Distribution of Body Weight, Height and Body Mass Index in a National Sample of Malaysian Adults. Medical Journal of Malaysia, 55, 108-128.

[23]López-García E, Raquel F, Leo'n-Mun oz L, María CZ, José RB \& Rodríguez-Artalejo F (2008), Sleep duration, general and abdominal obesity, and weight change among the older adult population of Spain. The American Journal of Clinical Nutrition, 87, 310-316.

[24]Luhrmann PM, Edelmann-Schafer B \& Neuhauser-Berthold M (2010), Changes in resting metabolic rate in an elderly German population: cross-sectional and longitudinal data. The Journal of Nutrition Health and Aging, 14, 232-236. http://dx.doi.org/10.1007/s12603-010-0055-4

[25] McLaren L (2007), socioeconomic status and obesity. Epidemiologic reviews, 29, 29-48. http://dx.doi.org/10.1093/epirev/mxm001.

[26] Mokdad AH, Bowman BA, Ford ES, Vinicor F, Marks JS \& Koplan JP (2001), The continuing epidemics of obesity and diabetes in the United States. The Journal of the American Medical Association, 286, 1195-1200. http://dx.doi.org/10.1001/jama.286.10.1195.

[27] Mokdad AH, Marks JS, Stroup DF \& Gerberding JL (2004), Actual causes of death in the United States, 2000. Journal of the American Medical Association, 291, 1238-1245. http://dx.doi.org/10.1001/jama.291.10.1238.

[28] National Cholesterol Education Program (NCEP) Expert Panel on Detection, Evaluation, and Treatment of High Blood Cholesterol in Adults (Adult Treatment Panel III) (2002). Third Report of the National Cholesterol Education Program (NCEP) Expert Panel on Detection, Evaluation, and Treatment of High Blood Cholesterol in Adults (Adult treatment panel III) final report, 2002. Circulation, 106, $3143-$ 3421 .

[29] National Institutes of Health, 1998. Clinical guidelines on the identification, evaluation, and treatment of overweight and obesity in adults: the evidence report. Bethesda, MD: National Heart, Lung, and Blood Institute in cooperation with The National Institute of Diabetes and Digestive and Kidney Diseases, NIH publication 98-4083.

[30]Obesity. World Health Organization, 2008. Available at http://www.who.int/topics/obesity/en/. Accessed January 2, 2015.

[31]O'Rahilly S \& Farooqi IS (2006), Genetics of obesity. Philosophical Transactions of the Royal Society of London .Series B: Biological Sciences, 361, 1095-1105. http://dx.doi.org/10.1098/rstb.2006.1850.

[32]Pednekar MS (2008), Association of body mass index with all-cause and cause-specific mortality: Findings from a prospective cohort study in Mumbai (Bombay), India. International Journal of Epidemiology, 37, 524-35. http://dx.doi.org/10.1093/ije/dyn001.

[33]Puoane T, Steyn K, Bradshaw D, Laubscher R, Fourie J, Lambert V \& Mbananga N (2002), Obesity in South Africa: the South African demographic and health survey. Obesity Research, 10, 1038-1048. http://dx.doi.org/10.1038/oby.2002.141.

[34] Ramachandran a \& Snehalatha C (2010), Rising burden of obesity in Asia. J Obes, 9, 116-21.

[35] Roskam AJ, Kunst AE, Van-Oyen H, Demarest S, Klumbiene J, Regidor E, Helmert U, Jusot F, Dzurova D \& Mackenbac JP, et al., (2010), Comparative appraisal of educational inequalities in overweight and obesity among adults in 19 European countries. Interna- 
tional Journal of Epidemiology, 39, 392-404. http://dx.doi.org/10.1093/ije/dyp329.

[36]Serena T, Terry B, Ru Y \& Gary EF (2009), Type of Vegetarian Diet, Body Weight, and Prevalence of Type 2 Diabetes. Diabetes Care, 32, 791-796. http://dx.doi.org/10.2337/dc08-1886.

[37]Stevens J, McClain JE \& Truesdale KP (2008), Selection of measures in epidemiologic studies of the consequences of obesity. International journal of obesity (London), 32(suppl 3), S60-66.

[38]St-Onge MP \& Gallagher D (2010), Body composition changes with aging: the cause or the result of alterations in metabolic rate and macronutrient oxidation? Nutrition, 26, 152-155. http://dx.doi.org/10.1016/j.nut.2009.07.004.

[39] Strohl KP, Strobel RJ \& Parisi RA (2004), Obesity and pulmonary function. In: Bray GA, Bouchard C, James WP, (Eds). Handbook of obesity: etilogy and pathophysiology, 2nd ed. New York, Marcel Dekker, pp. 725-739.

[40]Suter PM (2005), Is alcohol consumption a risk factor for weight gain and obesity? Critical Review in Clinical laboratory sciences, 42, 197227. http://dx.doi.org/10.1080/10408360590913542.

[41] Tiwari R, Srivastava D \& Gour N (2009), A Cross-sectional Study to Determine Prevalence of Obesity in High Income Group Colonies of Gwalior City. Indian Journal of Community Medicine, 34, 218-222. http://dx.doi.org/10.4103/0970-0218.55287.

[42] Van der Sande MA, Walraven GE, Milligan PJ, Banya WA, Ceesay SM, Nyan OA \& McAdam KP (2001), Family history: an opportunity for early interventions and improved control of hypertension, obesity and diabetes. Bulletin of the World Health Organization, 79, 321-328.

[43] Veghari G, Sedaghat M, Joshgani H, Banihashem S, Moharloei P, Angizeh A, Tazik E \& Moghaddami A (2013), Obesity and risk of hypercholesterolemia in Iranian northern adults. ARYA Atheroscler, 9 , 2-6.

[44]Vioque J, Torres A \& Quiles J (2000), Time spent watching television, sleep duration and obesity in adults living in Valencia, Spain. International Journal of Obesity and Related Metabolic Disorders, 24, 16831688. http://dx.doi.org/10.1038/sj.ijo.0801434.

[45]World Health Organization (2000), Obesity: preventing and managing the global epidemic. Report of a WHO consultation. World Health Organisation Technical Report Series, 894, 1-253.

[46] Yancey AK, Wold CM, McCarthy WJ, Weber MD, Lee B, Simon PA \& Fielding JE (2004), Physical inactivity and overweight among Los Angeles County adults. American Journal of Preventive Medicine, 27, 146-152. http://dx.doi.org/10.1016/j.amepre.2004.03.012.

[47]Yusuf U, Mehmet U, Ozlem A, Yasar MA, Ismail K, Mehmet TE \& Selim YS (2012), High prevalence of obesity in Tokat, a northern province of Turkey. The Journal of the Pakistan Medical Association, 62, 435-440.

[48] Yu Y (2012), Educational Differences in Obesity in the United States A Closer Look at the Trends. Obesity, 20, 904-908. http://dx.doi.org/10.1038/oby.2011.307. 